\title{
THE FIRST PRIVATISATION POLICY IN LATIN AMERICA: SELLING STATE-OWNED ENTERPRISES IN 1948-1950 PUERTO RICO*
}

\author{
GERMÀ BEL \\ Universitat de Barcelona (GiM-IREA) \& Barcelona Graduate \\ School of Economics ${ }^{\text {a }}$
}

\begin{abstract}
In the 1940s, when the governor of Puerto Rico was still appointed by the U.S. president, a large state-owned enterprise (SOE) sector was established. Later, in 1948-1950, the island's first elected government privatised these SOEs. This paper documents both the creation of the SOE sector and its privatisation, and analyses the role played by ideology, political interests and economic concerns in the decision to privatise. Whereas ideological factors might have played a significant role in the building of the SOE sector, the privatisation process was driven by economic factors. In the cement sector, the competing private firm was more efficient and the SOEs in other sectors with no private competitors in the island showed permanent losses.
\end{abstract}

Keywords: public enterprise, privatisation, industrial policy, Puerto Rico

Jel Code: L32, L33, L52, N46

* Received 1 September 2010. Accepted 8 June 2011. This research received financial support from the Spanish government (SEJ2006-04985 and ECO2009-06946), the government of Catalonia (SGR2009-1066) and ICREA-Academia. Most of this work was done while I was a visiting scholar at Universidad de Puerto Rico (UPR). I have benefited from open access to the Colección Puertorriqueña in the UPR Library, and the Historical Archive of the Fundación Luis Muñoz Marín. María E. Ordóñez Mercado (CP-Library UPR) and Julio Quirós (Fundación LMM) were extremely helpful. I am particularly indebted to Silvia Álvarez Curbielo, who first directed my attention to privatisation in Puerto Rico. I have benefited from comments and suggestions from Ricardo Alegría, Francisco Catalá, Fernando Fernández, Manuel Gonzalez, Mariluz Jiménez, Ana Matanzo, Efrén Rivera and two anonymous referees.

a Departament de Política i Estructura Econòmica Mundial, Universitat de Barcelona, Avd. Diagonal 690, 08034 Barcelona, Spain, gbel@ub.edu 


\section{RESUMEN}

En los 1940s, cuando el Gobernador de Puerto Rico era aún designado por el Presidente de EEUU, se construyó un gran sector público empresarial. Más tarde, en 1948-1950, el primer gobierno electo de la isla privatizó esas empresas. Este trabajo documenta la creación de empresas públicas y su privatización en Puerto Rico, y analiza el papel desempeñado en la privatización por la ideología, los intereses políticos y las motivaciones económicas. Mientras que factores ideológicos pudieron ser importantes en la creación del sector público empresarial, en la privatización jugaron un papel clave factores económicos como la superior eficiencia de la empresa privada competidora en el sector de cemento, y las continuas pérdidas experimentadas en el resto de empresas manufactureras públicas.

Palabras clave: empresa pública; privatización; política industrial; Puerto Rico

\section{INTRODUCTION}

Most economics and public policy scholars consider the privatisations in Chile (1970s-early 1980s) and the United Kingdom (1980s-early 1990s) to be the first privatisation policies in modern history (Yergin and Stanislaw 1998, p. 115). Others argue that the first privatisation operation was the denationalisation of steel in the United Kingdom in 1953 (Burk 1988), and a few scholars see the partial sales of state-owned enterprises (SOEs) in Germany under Adenauer's government (late 1950s-early 1960s) as the first large-scale privatisation programme (Megginson 2005, p. 15; Schipke 2001, p. 50). However, recently published works have documented and analysed a largescale privatisation policy between 1934 and 1937 in Germany, under Hitler's government (Bel 2006, 2010). Another recent study has examined a largescale privatisation under Mussolini's first government in Fascist Italy, between 1922 and 1925 (Bel forthcoming).

Contemporary economic analyses of privatisation have so far neglected an important, early case of large-scale privatisation: the one carried out by the first democratically elected governor of Puerto Rico in the late 1940s, which appears to have been the first large-scale privatisation policy implemented in a democratic regime ${ }^{1}$. A number of studies of industrial and

${ }^{1}$ I am aware of one previous privatisation operation (with transfer of full control to the private sector) implemented by a democratic government: in 1928, the Australian government sold a fleet of cargo ships that had been purchased during the World War I (Neville 1950, pp. 18-19). 
administrative policy in Puerto Rico in the 1950s (Chase 1951; Ojuda 1954; Ross 1957; Baer 1959; Lewis 1955) and 1960s (Goodsell 1965; Ross 1966) noted the sale of SOEs between 1948 and $1950^{2}$. However, none of these works provided an analysis of the process or the objectives of the privatisation policy implemented. Indeed, providing an analysis of the process and the objectives is the main contribution of this study.

Within 2 years of the first democratic gubernatorial election in Puerto Rico in 1948, the government of the Partido Popular Democrático (PPD; Democratic Popular Party) had privatised all the state-owned manufacturing firms. These firms belonged to a wide range of sectors: cement, glass, shoes, paper and chalkboard and clay products. The enterprises transferred to the private sector had been created during the 1940s in an attempt to promote industrialisation, and had been managed by the island's government. The nationalisation of existing public services companies (such as water, transport and energy) and the creation of SOE sectors was an important policy in Puerto Rico in the early 1940s.

Nationalisation and the expansion of the SOE sector were common in other countries during the decade, but Puerto Rico was alone in reversing the trend and developing a policy of privatisation of state-owned firms in the late 1940s. In fact, in the post-war period, no other country engaged in such a policy until 1959, when Germany embarked on a privatisation programme ${ }^{3}$. Hence, a central question remains to be answered: why did the Puerto Rican government depart from the mainstream policies regarding state ownership in the post-World War II era, by privatising state-owned firms?

Answering these questions requires an analysis of the objectives of the country's privatisation scheme. This paper intends to fill a gap in the economic literature by tracing the course of privatisation in 1948-1950 Puerto Rico through a study of: (1) Muñoz Marín's personal archive (accessible after the Fundación Luis Muñoz Marín was created in 1980 ${ }^{4}$; and (2) the documentation of the Puerto Rico Industrial Development Company, which only became available when it was donated to the Fundación Luis Muñoz Marín in December 2008. The analysis of privatisation in Puerto Rico suggests that the objectives pursued by the island's government were mostly related

\footnotetext{
(F'note continued)

This operation, which was in fact a reprivatisation, was an isolated measure and it was not implemented within the framework of a wide privatisation policy.

2 Ross's (1966) account is briefly followed in a study by Dietz (1986, pp. 215-216) when describing the basic characteristics of the sale of state-owned firms. Dietz does not add any original research or further analysis.

3 Although on a smaller scale than that applied in Puerto Rico, only three firms were partially privatised: Preussag in 1959, Volkswagen in 1961 and VEBA in 1965 (Schipke 2001, p. 50).

${ }^{4}$ Within Muñoz Marin's personal archive held by the Fundación Luis Muñoz Marín, the following sources have been particularly useful: section IV, series 2 ((a) personal correspondence; (b) data and statistics)); section $\mathrm{V}$, series 16 (statistics and economic reports).
} 
to economic concerns. One key factor was the poor performance of the manufacturing SOEs; another was the desire to enhance Puerto Rico's ability to attract private capital (particularly from continental United States) to invest in industries. In contrast, fiscal objectives do not seem to have been an important issue in the decision to privatise, nor did strong ideological or political motivations play a significant role.

The rest of the paper is organised as follows. First (section 2), the building of the Puerto Rican SOE sector is documented. Next (section 3), the privatisation process and its results are examined. After this (section 4), an analysis of the objectives of the privatisation policy is presented. Finally, (section 5) the main conclusions are drawn.

\section{THE BUILDING OF THE SOE SECTOR}

In September 1941, Rexford G. Tugwell was appointed governor of Puerto Rico. A former professor at Columbia University, Tugwell had served as undersecretary in the Department of Agriculture in Roosevelt's first New Deal government. At that time, he had visited Puerto Rico, and on his return, in April 1934, he prepared a report for President Roosevelt. Tugwell's view of the transformation of Puerto Rico was that industrialisation would not occur unless the government took the initiative. This continued to be his approach when he became governor in 1941. Throughout his tenure, he made concerted efforts to promote a policy of government-induced industrialisation (Tugwell 1953, p. 147). Tugwell made his intentions very clear in his earliest speeches to the Puerto Rican Legislature (Tugwell 1942, p. 58).

On 18 November 1941, Tugwell appointed Teodoro Moscoso as coordinator of the island's affairs. Moscoso was to play a crucial role in the industrialisation programme soon to begin. To improve Tugwell's relationship with the Puerto Rican Legislature, he forged an alliance with Luis Muñoz Marín (Maldonado 1965, p. 3; Goldsmith et al. 1974, p. 144; Carr 1984, pp. 65-66), who had obtained the powerful position of president of the Senate (the highest post that a Puerto Rican politician could hold) after the November 1940 election. In the 1940 electoral campaign, Muñoz Marín's PPD had pledged to place primary emphasis on issues related to economic reform, instead of the traditional discussion of the island's political status. A majority in the Legislature was in favour of economic reform ${ }^{5}$ and Tugwell was able to pass the legislation required to create the legal framework for the government-led industrialisation policy. The key step was the approval by Act no. 188 (11 May 1942) of the Law of the Development Company,

\footnotetext{
5 However, the margin of the PPD's victory in 1940 was narrow: it had a majority of just one vote in the Senate. Data on Senatorial and Representative districts have been obtained from the Biblioteca Virtual de Puerto Rico (http://eleccionespuertorico.org/mapas/index_es.html, accessed on 2 June 2009).
} 
according to which «wide authorization to go into business was provided» (Tugwell 1947, p. 263).

The Puerto Rico Development Company (PRDC henceforth; in 1946, it was renamed the Puerto Rico Industrial Development Company, PRIDCO thereafter) was organised along the lines of the Chilean Development Company, which had been created several years before (Moscoso 1953, p. 60). Moscoso was appointed general manager of PRDC on 30 September 1942, and the company began operating in October. Its first (and most important) factory was Cementos de Puerto Rico (the Puerto Rico Cement Company), with assets of around U.S.\$2,000,000 (PRDC 1944, p. 30). The government's common stock participation in this venture ${ }^{6}$ was transferred to PRDC in 1943 (Descartes 1950, p. 4), and thereafter the federal participation was paid in full out of the profits (Moscoso 1953, p. 60).

In addition to PRDC, two other key agencies for the development programme were created in 1942: the Puerto Rico Planning Board and the Government Development Bank. Other sector-related agencies were created between 1941 and 1945 (Baer 1959, p. 647): The Water Resources Authority, the Transportation Authority, the Communications Authority, the Insular Sewerage Service and the Puerto Rico Aqueduct Service ${ }^{7}$. This put in place the institutional framework needed to develop the policy of government-led industrialisation.

All public enterprises were organised as independent public corporations; they were legally incorporated (thus placed outside the bureaucracy) and intended to be financially self-sufficient (Goodsell 1965, p. 183). In line with this modern approach to public management of commercial firms, Moscoso worked hard to make PRDC's operations profitable, and soon demanded that services that were provided free should be separated from the company's general services ${ }^{8}$.

In the following years, the newly created agencies took over several privately owned utilities. In January 1944, the Puerto Rico Water Resource Authority took over the Puerto Rico Railway Light and Power Company and the Mayagüez Light Power and Ice Company, bringing all electric power utilities in Puerto Rico under its control (Richardson 1947, p. 113). Later, the Transportation Authority took over the urban transport system in San Juan. This policy closely resembled those applied in many U.S. states and municipalities in the late $19^{\text {th }}$ and early $20^{\text {th }}$ centuries, a period characterised by a progressively greater involvement of governments in the delivery of local services (Gómez-Ibáñez 2003).

\footnotetext{
${ }^{6}$ Puerto Rico Cement Co. had begun operations in 1939, becoming the island's largest industrial factory.

7 These last two concerns merged in 1945 forming the Aqueduct and Sewer Authority (Goodsell, 1965, p. 189).

8 Moscoso, Letter to Rexford Tugwell, 30 June 1945. Muñoz Marín publicly endorsed Moscoso's view in a speech broadcast on 20 August 1945 (Muñoz Marín 2005, p. 87).
} 
What was exceptional in the Puerto Rican policy of the 1940s was the fact that the PRDC created new manufacturing plants, which were built and run by the following government corporations:

- The Puerto Rico Glass Corporation (PR Glass, henceforth) was incorporated on 24 February 1943 (PRDC 1944, p. 13). The construction of the factory began in May 1943 and glass production began in January 1945, but stopped because of a strike between 25 February and 25 June 1945 (PR Government 1945, p. 30). Production resumed after the strike.

- The Puerto Rico Pulp and Paper Corporation (PR Pulp and Paper, henceforth) was organised on 23 April 1944 (PRDC 1944, p. 13). Construction began in May 1944 and the production of paperboard began on 6 May 1946 (PR Government 1946, p. 39).

- The Puerto Rico Clay Products Corporation (PR Clay Products, henceforth) was created on 6 November 1944 (PRDC 1944, p. 13); the preliminary work for building the clay products factory was completed by June 1945. The first kiln was completed in May 1947 and production of brick and hollow tiles began in August 1947.

- The Puerto Rico Shoe and Leather Corporation (PR Shoe and Leather, henceforth) was incorporated in January 1946. The plant opened (although construction was still incomplete) on 1 July 1946 and commercial operations began in February 1947.

- Telares de Puerto Rico, inc. (PR Telares, henceforth) was incorporated in 1946 and work was scheduled to start before the end of 1946 (PR Government 1946, p. 38). However, the plant to be managed by PR Telares was never built, and this subsidiary was dissolved in June $1951^{9}$.

Table 1 provides details of PRIDCO's six subsidiary corporations. In most cases, actual investment was much higher than had initially been expected. According to Descartes (1950, p. 31), total direct investment of PRIDCO in the subsidiary plants until 30 June 1949 was U.S. $\$ 11.1$ million (133.1 million in 2010 U.S.\$), a large financial commitment. Table 2 displays information on the production and workforce of the subsidiaries in the final years of the 1940s, when all plants (but PR Telares) had begun commercial operations.

PRIDCO plants required large investments, but they employed relatively few workers: in June 1948, when all plants were in operation, the total workforce was only 992 employees $^{10}$. In fact, the creation of the manufacturing state-owned sector seems to have had a minimal effect on industrial employment, far below what an effective industrialisation policy for the island might

9 The total deficit accumulated until PR Telares was liquidated was U.S. $\$ 86,000$ (PRIDCO, 1951, p. 27).

${ }_{10}$ Moscoso, Letter to Luis Muñoz, Marín, 24 June 1948. 
TABLE 1

PRIDCO MANUFACTURING CORPORATIONS: ORGANISATION, OPERATIONS AND INITIAL INVESTMENT

\begin{tabular}{|l|c|c|c|c|c|}
\hline Corporation & $\begin{array}{c}\text { Date of } \\
\text { organisation }\end{array}$ & $\begin{array}{c}\text { Beginning of } \\
\text { commercial } \\
\text { operations }\end{array}$ & $\begin{array}{c}\text { Expected } \\
\text { investment } \\
\text { (U.S.\$) }\end{array}$ & $\begin{array}{c}\text { Actual initial } \\
\text { investment } \\
\text { (U.S.\$) }\end{array}$ & $\begin{array}{c}\text { Actual initial } \\
\text { investment } \\
\text { (U.S.\$ 2010) }\end{array}$ \\
\hline $\begin{array}{c}\text { Puerto Rico } \\
\text { Cement }\end{array}$ & $\begin{array}{c}\text { February } \\
1938^{\mathrm{a}}\end{array}$ & January 1939 & n.a. & $1,500,000$ & $23,423,531$ \\
\hline $\begin{array}{c}\text { Puerto Rico } \\
\text { Glass }\end{array}$ & $\begin{array}{c}\text { February } \\
1943\end{array}$ & January 1945 & $2,000,000$ & $3,026,000$ & $39,172,057$ \\
\hline $\begin{array}{c}\text { Puerto Rico Pulp } \\
\text { and Paper }\end{array}$ & April 1944 & May 1946 & $1,200,000$ & $1,504,436$ & $18,907,928$ \\
\hline $\begin{array}{c}\text { Puerto Rico Clay } \\
\text { Products }\end{array}$ & $\begin{array}{c}\text { November } \\
1944\end{array}$ & August 1947 & 247,505 & $1,140,595$ & $14,012,837$ \\
\hline $\begin{array}{c}\text { Puerto Rico Shoe } \\
\text { \& Leather }\end{array}$ & $\begin{array}{c}\text { January } \\
1946\end{array}$ & February & n.a. & 319,247 & $3,837,696$ \\
\hline $\begin{array}{c}\text { Telares de Puerto } \\
\text { Rico }\end{array}$ & Early 1946 & Never & - & $86,000^{\mathrm{b}}$ & $1,033,813$ \\
\hline
\end{tabular}

n.a.: not available.

Notes: ${ }^{a}$ The Cement plant was acquired by PRDC in 1943 , with assets close to U.S. $\$ 2,000,000$.

${ }^{\mathrm{b}}$ The amount for Telares de Puerto Rico Inc. is the deficit accumulated by 30 June 1951.

Sources: Author's own data, based on: (a) PRDC (1944); (b) PRIDCO (1947 and 1951); (c) PR government (1945 and 1946). U.S.\$2010: author's computation based on CIP indexes of Bureau of Labor Statistics (U.S. Department of Labor).

TABLE 2

PRIDCO MANUFACTURING CORPORATIONS: PRODUCTION (JULY-JUNE) AND WORKFORCE

\begin{tabular}{|l|c|c|c|c|}
\hline Corporation & $\mathbf{1 9 4 6 - 1 9 4 7}$ & $\mathbf{1 9 4 7 - 1 9 4 8}$ & $\mathbf{1 9 4 8 - 1 9 4 9}$ & $\begin{array}{c}\text { Work force } \\
\text { (June 1948) }\end{array}$ \\
\hline Puerto Rico Cement (barrels of cement) & 805,393 & 949,278 & $1,028,463$ & 156 \\
\hline Puerto Rico Glass (tons of glass packed) & 12,900 & 7,557 & 18,387 & 176 \\
\hline Puerto Rico Pulp and Paper (tons) & 5,365 & 3,293 & 5,980 & 173 \\
\hline Puerto Rico Clay Products (tons) & - & n.a. ${ }^{\text {b }}$ & n.a. ${ }^{\text {b }}$ & 205 \\
\hline $\begin{array}{l}\text { Puerto Rico Shoe \& Leather (pairs of } \\
\text { shoes) }\end{array}$ & $74,700^{\text {a }}$ & 245,456 & 316,083 & 282 \\
\hline
\end{tabular}

Notes: ${ }^{\text {P}}$ Production of shoes began in February 1947.

${ }^{\mathrm{b}}$ Production of clay products began in August 1947. Given the heterogeneity of the corporation's outputs, it is not possible to provide an overall figure for annual production.

Sources: Author's own data, based on PRIDCO $(1947,1948,1949)$. Workforce: Moscoso, Letter to Luis Muñoz Marín, 24 June 1948. 
have been expected to achieve. Because most PRIDCO plants were capital intensive, their workforce represented only 1.6 per cent of the island's employment in manufacturing ${ }^{11}$.

\section{PRIVATISATION OF THE STATE-OWNED MANUFACTURING FIRMS}

On 12 February 1946, Tugwell delivered his last governor's message to the Legislature. Tugwell (1947, p. 49) concluded as follows:

"It is with some emotion that I tell you at the opening of this regular session of my approaching departure.... I have already noted some of the credits, the largest being the program for economic rehabilitation which has been begun. And next, perhaps, the public ownership and operation of public utilities.»

The $46^{\text {th }}$ annual report (1945-1946) was the last one delivered by Tugwell, who was replaced shortly afterwards by Jesús T. Piñero, the first native governor of Puerto Rico.

Piñero was the last governor to be appointed by the U.S. president. Interestingly, Muñoz Marín - still president of the Senate at the time - had been offered the governorship, but he preferred to wait until the first gubernatorial election, scheduled for November 1948. Following Muñoz Marín's suggestion, Piñero, a PPD member, was appointed to the office. In any case, thereafter Muñoz Marín held total command of the executive power in Puerto Rico, adding this to the full control the PPD had obtained over the Legislature. Whereas the PPD had won the 1940 election to the Legislature by a very narrow margin, the 1944 election had produced the largest victory in the history of Puerto Rico: the PPD took all seven Senatorial districts and thirty-four of the thirty-five Representative districts, thus gaining full control of the Legislature.

Together with these institutional changes, the economic environment had also changed dramatically after the end of the World War II. Maritime transportation and trade in the Caribbean Sea progressively returned to normal, thus increasing the competition facing the commercial products manufactured in the island. This change was of great importance. The decision to establish a state-owned manufacturing sector had been taken within the pre-war and wartime context, when the growing tension and subsequent hostilities profoundly affected maritime transportation and commerce in the Caribbean, particularly between 1942 and 1944. Hence, most government-owned manufacturing firms had been designed to supply the local market (Moscoso 1953,

11 In 1948, 64,085 workers were employed in manufacturing (excluding home needlework (PRIDCO, 1949, p. 4)). 
p. 61); by the time all five subsidiaries were finally in full commercial operation in 1947, the market conditions on the island had changed dramatically. In addition, technical and commercial problems had seriously affected the performance of some of the subsidiaries, especially the PR Pulp and Paper Co., and the PR Shoe and Leather $\mathrm{Co}^{12}$.

The Puerto Rican government followed these developments closely, and expressed its official views in the annual reports to the Legislature (see Table 3 ). Tugwell's reports (1941-1946) had supported the increasing role of the government in manufacturing. Projects were expanding each year, and emphasis was placed on the development of the factories. The reports also mentioned the difficulties caused by labour conflicts and the extra costs of investments.

The $47^{\text {th }}$ report (1946-1947), delivered by Piñero, differed little from the last one presented by Tugwell. However, the following report (that of 19471948) explicitly stated that PRIDCO had turned its attention to two important aspects of the long-term programme: encouragement of private industrial enterprise, and the development of tourism as a source of income for the island. Publicly managed manufacturing firms received much less attention in the report, thus providing a clear signal that a reorientation of the development policy was underway.

Interestingly, the $49^{\text {th }}$ report (1948-1949), the first delivered by Muñoz Marín, openly admitted that selling the PR Pulp and Paper Co. to private interests could be a solution for its problems. In his second governor's report $\left(50^{\text {th }}, 1949-1950\right)$, Muñoz Marín emphasised that the PR Shoe and Leather Co. had been privatised, that most PRIDCO plants were operating at a loss and that profits were falling in the only profitable firm, the PR Cement Co. The question of privatisation had irreversibly entered the fray.

Although contemporary studies claimed that 1948 was the year in which the decision to sell the subsidiaries was first made (Ross 1966, p. 111), the possibility of privatisation was already being discussed by PRIDCO in mid-1947. At a meeting of the PRIDCO Planning and Executive Committees held on 30 May 1947, Moscoso reported on negotiations held during a recent trip to the United States regarding the transfer of the shoe factory to a private firm:

«2. Shoe factory - It was reported that Mr. Weinbrot of Mercury Footwear reiterated the firm's willingness to consider renting the company's shoe factory. The President [Moscoso] stated that a letter to that effect should be obtained from Mr. Weinbrot but that it would be preferable to negotiate along these lines with either Penaljo or Joyce, two other reputable shoe manufacturers of apparently higher standards.» ${ }^{13}$

12 Moscoso (1953, p. 61) and Ross (1966, pp. 64-73) provide accounts of the problems faced by these subsidiaries.

13 PRIDCO, Minutes of the meeting. Muñoz Marín was well aware of this, as a copy of these minutes was sent to him, as usual. 
TABLE 3

THE SOE SECTOR IN PUERTO RICAN GOVERNORS' AR

\begin{tabular}{|c|c|c|c|}
\hline Report & Governor & SOEs in the governor's AR & Emphasis \\
\hline $\begin{array}{c}43^{\text {rd }} \text { AR } \\
1943\end{array}$ & Tugwell & $\begin{array}{l}\text { PR Glass Co. is already underway. } \\
\text { Expected investment is U.S. } \$ 2,000,000 . \\
\text { Other projects under consideration: } \\
\text { (1) plant for the manufacture of wall } \\
\text { board; (2) textile mill; (3) hosiery } \\
\text { knitting mill; (4) paper mill; (5) yeast } \\
\text { plants; (6) plant for the production of } \\
\text { edible oils and fats and laundry soaps }\end{array}$ & $\begin{array}{l}\text { Ambitious projects } \\
\text { for building publicly } \\
\text { operated plants }\end{array}$ \\
\hline $\begin{array}{c}44^{\text {th }} \text { AR } \\
1944\end{array}$ & Tugwell & $\begin{array}{l}\text { Virtual completion of the glass container } \\
\text { plant, with a total investment of } \\
\text { U.S. } \$ 2,276,890 \text {. Creation of the PR Pulp } \\
\text { and Paper Co., and the beginning of } \\
\text { construction of a paper mill in May } 1944 \text {. } \\
\text { Expected cost to be U.S. } \$ 1,200,000\end{array}$ & $\begin{array}{l}\text { Cost of the glass } \\
\text { container plant } 14 \% \\
\text { above expectations }\end{array}$ \\
\hline $\begin{array}{c}45^{\text {th }} \text { AR } \\
1945\end{array}$ & Tugwell & $\begin{array}{l}\text { Glass production began in January 1945; a } \\
\text { strike in February stopped production for } \\
86 \text { days. Building of the paperboard mill } \\
\text { was repeatedly held up by delays in } \\
\text { delivery of construction material and } \\
\text { machinery; total capital stock issued } \\
\text { amounted to U.S. } \$ 1,325,000 \text {. The PR Clay } \\
\text { Products Co. was organised late in 1944; } \\
\text { funds available for use amount to } \\
\text { U.S. } \$ 247,504.75 \text {. Plans under considera- } \\
\text { tion by the Research and Development } \\
\text { Department include plants for making } \\
\text { wallboard, cotton cloth, food yeast, shoes, } \\
\text { vegetable oils and meat packing }\end{array}$ & $\begin{array}{l}\text { Paper mill costs } \\
\text { more than } 10 \% \\
\text { above expected. } \\
\text { Problems in glass } \\
\text { production and } \\
\text { paper plant } \\
\text { construction. } \\
\text { Nevertheless, } \\
\text { ambitious plans to } \\
\text { be implemented }\end{array}$ \\
\hline $\begin{array}{c}46^{\text {th }} \text { AR } \\
1946\end{array}$ & Tugwell & $\begin{array}{l}\text { By the end of the fiscal year, PRIDCO } \\
\text { had six subsidiary corporations: PR } \\
\text { Glass Co., PR Cement Co., PR Pulp and } \\
\text { Paper Co., PT Clay Products Co., PR } \\
\text { Shoes and Lather Co., and Telares de } \\
\text { PR. Glass, Cement and Pulp and Paper } \\
\text { were in operation, Clay, and Shoes } \\
\text { and Leather were under construction; } \\
\text { construction of Telares was expected to } \\
\text { start by the end of } 1946\end{array}$ & $\begin{array}{l}\text { Three subsidiaries } \\
\text { working, and two } \\
\text { plants being built. } \\
\text { Construction of } \\
\text { Telares scheduled }\end{array}$ \\
\hline $\begin{array}{c}47^{\text {th }} \text { AR } \\
1947\end{array}$ & Piñero & $\begin{array}{l}\text { The PR Shoe and Leather Co. went } \\
\text { into operation, and the subsidiary to } \\
\text { manufacture heavy clay products had }\end{array}$ & $\begin{array}{l}\text { Four subsidiaries } \\
\text { working, and one } \\
\text { plant to begin }\end{array}$ \\
\hline
\end{tabular}


TABLE 3 (Cont.)

\begin{tabular}{|c|c|c|c|}
\hline & & $\begin{array}{l}\text { successful test-runs. All of the foregoing } \\
\text { contributes to the fulfillment of the basic } \\
\text { programme approved by the island's } \\
\text { government when the PRDC was founded } \\
\text { in } 1942 \text {. To achieve this, the company has } \\
\text { developed basic industries such as } \\
\text { cement, glass, clay products, paper and } \\
\text { shoes. The Company has scheduled } \\
\text { construction of a new textile mill in } \\
\text { Ponce, which will employ more than } \\
500 \text { persons, and has contracted for the } \\
\text { building of a yeast pilot plant capable of } \\
\text { producing } 1,000 \text { pounds of dry yeast daily }\end{array}$ & $\begin{array}{l}\text { commercial } \\
\text { operations soon. } \\
\text { Basic PRDC } \\
\text { programme } \\
\text { completed. } \\
\text { Construction of } \\
\text { Telares scheduled }\end{array}$ \\
\hline $\begin{array}{c}48^{\text {th }} \text { AR } \\
1948\end{array}$ & Piñero & $\begin{array}{l}\text { PRIDCO has laid special emphasis on } \\
\text { two important aspects of the long-term } \\
\text { programme: encouragement of private } \\
\text { industrial enterprise and the development } \\
\text { of tourism as a source of income. }\end{array}$ & $\begin{array}{l}\text { More emphasis on } \\
\text { promoting private } \\
\text { industrial firms }\end{array}$ \\
\hline $\begin{array}{c}49^{\text {th }} \text { AR } \\
1949\end{array}$ & $\begin{array}{r}\text { Muñoz } \\
\text { Marín }\end{array}$ & $\begin{array}{l}\text { The PRIDCO programme began with the } \\
\text { acquisition of a cement plant, and later } \\
\text { the creation of four other industrial } \\
\text { plants, three of which showed signs of } \\
\text { becoming profitable ventures. PR Glass, } \\
\text { PR Clay, PR Shoe and Leather, and PR } \\
\text { Pulp and Paper all operated at a loss. The } \\
\text { solution to the difficulties of this plant } \\
\text { (Pulp and Paper) appeared to be either to } \\
\text { adapt it to the manufacture of cardboard } \\
\text { or to sell it to private interests who would } \\
\text { make an integrated enterprise }\end{array}$ & $\begin{array}{l}\text { Privatisation of PR } \\
\text { Pulp and Paper Co. } \\
\text { envisaged as a likely } \\
\text { solution for its } \\
\text { difficulties }\end{array}$ \\
\hline $\begin{array}{c}50^{\text {th }} \text { AR } \\
1950\end{array}$ & $\begin{array}{r}\text { Muñoz } \\
\text { Marín }\end{array}$ & $\begin{array}{l}\text { During the year Joyce of Puerto Rico, a } \\
\text { subsidiary of Joyce Inc. of California, } \\
\text { leased the PRIDCO's shoe factory at } \\
\text { Ponce. The PR Clay Co. and the PR Glass } \\
\text { Co. operated at a loss. Production by the } \\
\text { Cement Corporation was interrupted by } \\
\text { a } 50 \text {-day strike, which caused a sharp } \\
\text { drop in earnings. The plant had a net } \\
\text { profit of U.S. } \$ 758,000 \text { compared with } \\
\text { U.S. } \$ 1,271,000 \text { in the previous year }\end{array}$ & $\begin{array}{l}\text { PR Shoe and Leather } \\
\text { Co. privatised. PR } \\
\text { Cement Co. profits } \\
\text { decreased; other } \\
\text { plants show a loss }\end{array}$ \\
\hline
\end{tabular}

SOE: state-owned enterprise; AR: annual reports; PRDC: Puerto Rico Development Company; PRIDCO: Puerto Rico Industrial Development Company.

Note: Fiscal years: 1 July-30 June.

Source: Author's own data, based on PR government reports (1943, p. 47; 1944, p. 31; 1945, pp. 30-31; 1946 , pp. $38-39 ; 1947$, pp. $93-97$; 1948 , p. $60 ; 1949$, pp. $60-65 ; 1950$, pp. $88-90)$. 
In fact, the shoe and leather factory was sold to Joyce of California in October 1949. However, more negotiations were needed before the privatisation policy could finally proceed.

As early as May $1948^{14}$, PRIDCO received an offer to buy all its five operating subsidiaries, from a group headed by Royal Little, president of Textron. This proposal divided the subsidiaries into two groups - one formed by the cement plant, and the other formed by the remaining four. The proposal included: (1) payments in cash for prepaid items and inventories; (2) the payment of U.S. $\$ 3,000,000$ in cash for the cement plant (or alternatively a lease for 6 years at a rental of U.S. $\$ 500,000$ per year, and U.S. $\$ 100,000$ per year thereafter for 93 years); and (3) the payment of the depreciated value of the four other plants over 10 years with 3 per cent interest payable quarterly ${ }^{15}$. This proposal would have resulted in a payment well below the net investment made by PRIDCO in the subsidiaries, which had been set as the minimum sum to be met for the approval of any sale, and accordingly it was turned down.

Even though the Puerto Rican government would not make any official statement on its willingness to privatise PRIDCO subsidiaries before the gubernatorial election of November 1948, the question of privatisation was debated publicly. In early July 1948, Luis Ferré, one of the leaders of the Statehood Party (and a member of the Ferré Group, a family industrial holding that would be crucial later in the sale of the subsidiaries) made a public statement asking that the firms be sold at auction, in which Puerto Rican firms should participate ${ }^{16}$.

New proposals for the acquisition of the subsidiaries were soon forthcoming. Following a conversation held with Moscoso on 1 February 1949, David G. Baird (vice-president of Marsh \& McLennan Inc.) sent PRIDCO a formal bid to buy the cement, glass, paper and clay product companies ${ }^{17}$. One week later, on 7 February 1949, Moscoso sent Baird's letters to PRIDCO's board of directors, together with a memorandum stating his opinion that

«it is an operation to be studied in detail .... I want to let you know in advance that our recommendation will probably be to ask for a higher amount regarding the 'going-concern value' of all plants. Perhaps one or two million dollars in addition to the millions offered. Furthermore, the accumulated deficits must be absorbed by the company that buys the plants. ${ }^{18}$

14 That is, long before the proposal for the acquisition of the paperboard plant made by Karl F. Landegger by the end of 1949, which is considered by Ross (1966, p. 115) as the first formal proposal to buy a PRIDCO subsidiary.

${ }_{15}$ PRIDCO, Proposal for the sale of subsidiaries. All the details of the proposal can be found in this PRIDCO internal memorandum.

16 El Mundo, 7 July 1948, p. 1.

17 Details of this proposal can be found in Baird, Letter to PRIDCO.

18 PRIDCO, Memorandum from Teodoro Moscoso (author's translation). 
No agreement was reached between PRIDCO and Baird, but the subsidiaries would soon be privatised. In October 1949, PRIDCO sold the PR Shoe and Leather Co. to Joyce de Puerto Rico Inc., a subsidiary of Joyce of California. Joyce purchased the machinery for U.S. $\$ 35,000^{19}$. More importantly, at the end of 1949 the New York businessman Karl F. Landegger showed an interest in acquiring the paper plant. In July 1950, he submitted a formal bid for the acquisition of all four subsidiaries still under PRIDCO ownership (cement, glass, paper, clay products). The nominal price he offered was U.S. $\$ 10,000,000$, to be paid in 10 years. However, Landegger offered only U.S. $\$ 2,000,000$ as a down payment and an interest-free mortgage $^{20}$. Although the total amount offered was close to the book value of the plants, the interest-free mortgage made the proposal far less attractive, and PRIDCO did not accept it.

The final step was in late September 1950, when the Puerto Rican Ferré Group unexpectedly ${ }^{21}$ offered U.S. $\$ 10,500,000$, to be paid as follows: a down payment of U.S. $\$ 2,000,000,3.5$ per cent preferred stock of another U.S. $\$ 2,000,000$, and a 4 per cent first mortgage of U.S. $\$ 6,500,000^{22}$. This proposal was the first to meet PRIDCO's demands in full, and an agreement was reached less than 1 week after intense negotiations between the technical teams of PRIDCO and the Ferré Group to work out the details ${ }^{23}$. On 3 October, the official agreement to sell the cement, glass, paper and clay products companies to the Ferré Group was publicly announced ${ }^{24}$.

The total amount agreed for the sale, U.S. $\$ 10,500,000$, was slightly above the book value of PRIDCO's subsidiaries ${ }^{25}$. The quantitative significance of the sale can hardly be understated. Proceeds from privatisation amounted to 9.3 per cent of fiscal receipts for the island's government purposes, and to 1.4 per cent of Puerto Rico's total gross product in $1950^{26}$. PRIDCO saw the operation as a «commercial deal that, from the point of view of valuations and economic consequences involved, may be classified among the

\footnotetext{
19 Joyce agreed to add at least U.S.\$65,000 worth of additional machinery, and took over the factory building on a lease basis (PRIDCO 1950, p. 36). Full details of the operations can be found in PRIDCO (1950, p. 20).

20 See further details of Landegger's proposal in Ross (1966, p. 115).

21 While PRIDCO was still considering the possibility of selling the firms to Landegger if he improved his offer, the Ferré Group asked Martin Muñoz to withhold any final decision until that holding could make an offer for PRIDCO subsidiaries; Muñoz complied with this request (Muñoz Marín 1992, p. 252).

22 Taking everything into account, the Ferré proposal amounted to U.S.\$3,000,000 over the bid offered by Landegger (Ross, 1966, p. 116).

23 Maldonado (1997, pp. 65-68) offers a vivid account of this negotiation process.

${ }_{24}$ El Mundo, 4 October 1950, pp. 1 and 15; El Imparcial, 4 October 1950, pp. 2 and 34.

25 Note that the PR Shoe and Leather had already been sold to Joyce in November 1949, well before this agreement was reached.

${ }^{26}$ I have made these computations based on the data in Puerto Rico Planning Board (1951) on fiscal receipts (p. 79, Table 46), and gross product (p. 162, Appendix Table 14).
} 
most important ever made in the history of Puerto Rico» ${ }^{27}$. Indeed, the relevance of proceeds from privatisation with respect to fiscal receipts (9.3 per cent) was much higher than that obtained between 1934 and 1937 in Nazi Germany, which averaged 1.4 per cent per year (Bel 2010), and in Fascist Italy between 1922 and 1925 (Bel forthcoming). In the same way, the relevance of proceeds from privatisation with respect to fiscal receipts in Puerto Rico was higher than in most EU-15 countries during Europe's most intense period of privatisation $(1997-2000)^{28}$.

\section{ANALYSIS OF THE OBJECTIVES OF PRIVATISATION IN PUERTO RICO}

Contemporary authors paid little attention to the reasons why Puerto Rico's government privatised the manufacturing firms under its ownership. In 1954, a few years after privatisation had been implemented, Ojuda (1954, pp. 161-162) emphasised the economic and technical difficulties faced by most subsidiaries in undertaking successful operations (such as the market dimension and changes in the economic environment with the resumption of trade) as drivers of the sale. However, in an article published in 1955, Lewis (1955, pp. 625-627) stressed managerial incapacity as one of the reasons for the sale, as well as the view that government-owned firms would produce a dangerous increase in the island's wage structure because they paid higher wages than private firms. Two years later, in 1957, Ross (1957, pp. 88-89; 1966, pp. 108-117) refuted Lewis's views by emphasising that managerial incapacity was not an issue in the sale; Ross's reasoning was more in line with Ojuda's view that the sale of the subsidiaries was due to problems related to the dimension of the local market and to the economic environment.

Some of the contemporary analyses written in the 1960s are valuable, but the authors of these studies lacked the theories, concepts and tools supplied by recent literature. Theoretical developments have provided valuable hypotheses on the motivations of politicians choosing between public ownership and privatisation (Shleifer and Vishny 1994; Boycko et al. 1996; Bel and Calzada 2009), and have identified different objectives linked to privatisation policies (Vickers and Yarrow 1988, 1991). On the one hand, both the theoretical and the empirical literature have provided interesting results regarding the use of privatisation to obtain political support (Perotti 1995; Biais and Perotti 2002; Bortolotti et al. 2003; Bel and Fageda 2009). On the other, international evidence shows that financial motivations have also

27 PRIDCO (1951, p. 15, author's translation). The recovery of the capital used to establish the firms was later confirmed by the Puerto Rico Planning Board (1952, p. 38).

28 The figures for EU-15 countries in 1997-2000 can be obtained by combining data on privatisation receipts from Clifton et al. (2003, p. 95) and data on fiscal receipts from Organization for Economic Cooperation and Development (2005). 
been a key factor in recent privatisations (Yarrow 1999; Bortolotti and Milella 2008).

In all, the analyses of more recent privatisation experiences in the fields of economics and public policy have shown that privatisation policies may pursue a multiplicity of objectives, among which three types stand out: ideological motivations, political interests and economic objectives (either financial or efficiency-related). By using these concepts and tools, a deeper and systematic analysis of the objectives of privatisation in Puerto Rico can be undertaken.

\subsection{Ideological Motivations}

Ideology played an important role in the building of the SOE sector in Puerto Rico. In line with the belief (commonly held in the late 1930s and early 1940s) that private initiative would not effectively engage in the industrialisation of Puerto Rico, Rexford Tugwell was firmly convinced of the importance of public intervention in the economy. Tugwell held important posts in the U.S. Department of Agriculture in the mid-1930s, and the proposals he tried to put forward won him the nickname «Rex the Red» (Goodsell 1965, p. 165; Carr 1984, p. 67). Indeed, Tugwell's faith in public corporations and state-financed industry was one of the main drivers of the creation of the SOE sector in Puerto Rico (Carr 1984, p. 65). To achieve his objective, Tugwell enlisted the support of Muñoz Marín, the leading local politician, and Moscoso, who became the leading local public servant in the industrial sector. However, Tugwell's views on industrialisation were substantially to the left of those of Muñoz and Moscoso (Goodsell 1965, p. 190). Indeed, the fact that Tugwell left the governorship in 1946 was seen as one of the factors that made the industrial policy reorientation initiated after 1947 possible (Ross 1966, p. 79).

Particular attention should be paid to Muñoz Marín's views on the issue of public intervention and industrial development, because - in addition to being president of the Senate - he was also the undisputed leader of the PPD, and policy decisions were heavily dependent on him, particularly after Tugwell left Puerto Rico in 1946. The fact that Muñoz Marín did not share Tugwell's faith in nationalisation is reflected in their disagreement over the uncompleted nationalisation of the private telecommunications company. Nationalising telecommunications was one of Tugwell's most cherished projects, but it failed because of Muñoz Marín's lack of support. In 1947, Tugwell's public criticism of Muñoz Marín's position on the expropriation of telecommunications sparked fierce controversy. In a speech broadcast on 27 March 1947, Muñoz Marín responded

«I believe that investment of public funds directed to create more sources of production, or to stimulate them, should have priority over 
public investments... merely directed to transfer property ... I have never believed in the wisdom of investing public funds to merely transfer ownership to the government.» ${ }^{29}$

More on Muñoz Marín's views on the private vs. public debate in economics can be learnt from a speech given on the eve of the first election for governor, in November 1948, when he stated that

"Men in the entire world fight, some defending private initiative, others defending that the government should do everything .... We cannot be doctrinaire .... The Puerto Rican government works based on both doctrines, applying whichever one is more helpful in a particular moment. The government has created state-owned factories. But it has helped to make many more private factories .... we are neither theoretical nor doctrinaire.» ${ }^{30}$

Indeed, the privatisation policy itself provides clear proof that it did not emerge out of any ideological conviction concerning the systematic superiority of private ownership. Not one agency owning and operating public utilities or other network services (such as electricity, water or urban transportation) was privatised either between 1948 and 1950, or during the rest of Muñoz Marín's tenure, which ended in 1964.

\subsection{Political Interests}

We should now turn our attention to the question of whether political interests might have been the drivers of the privatisation policy. Recent theoretical literature has shown that governments can design and implement privatisation to foster their partisan political interests ${ }^{31}$. Furthermore, the privatisation policy that preceded the one implemented in Puerto Rico - the large-scale sale of government-owned enterprises in Germany between 1934 and 1937 - had clear political objectives, as well as financial ones. The Nazi government had come to power with limited parliamentary support ${ }^{32}$; as privatisation favoured private property, the Nazis used it as a tool to foster alliances with the great industrialists (Bel 2010). In Italy, Mussolini

${ }^{29}$ Muñoz Marín, «La compra de telefónica», (in Muñoz Marín, 2005, pp. 321-324; author’s translation).

30 Muñoz Marín, «Mi propósito es que el pueblo resuelva los difíciles problemas de su vida», (in Muñoz Marín, 2005, pp. 644-667; author's translation).

31 See Biais and Perotti (2002) and Perotti (1995) for theoretical analyses; see Bel and Fageda (2009) and Bortolotti et al. (2003) for empirical information.

32 When Hitler was appointed chancellor in January 1933, the Nazi party had just 196 out of 584 seats (33.6 per cent) in the German Parliament. In the next election, in March 1933, the Nazis obtained 44.5 per cent of the seats (Bel 2010). 
implemented a privatisation policy in 1922-1925 for largely the same reasons (Bel forthcoming) ${ }^{33}$.

In Puerto Rico, however, there was no comparable scenario of political weakness and limited parliamentary support when the privatisation programme was implemented. In the first gubernatorial election ever held, in 1948, Muñoz Marín obtained 61.2 per cent of the votes, and became the first elected governor of Puerto Rico. The second most voted candidate (belonging to a coalition of the Statehood Party, the Socialist Party and the Reformist Party) ${ }^{34}$ obtained just 28.6 per cent of votes, and the third candidate (the Independence Party) received 10.2 per cent ${ }^{35}$. As regards the elections to the Legislature, Muñoz Marín's PPD won all the senatorial and representative districts. Muñoz Marín now held absolute control of both the executive and the legislative branches, and he had no need of a coalition in order to design and implement his industrial policies.

In addition to the government's political strength in 1948, another striking factor sets the Puerto Rico experience apart from other large-scale privatisation processes implemented to favour business and political elites and to benefit the government's allies, such as Fascist Italy (Bel forthcoming), Nazi Germany (Sweezy 1941; Merlin 1943; Bel 2010) or post-communist Russia (Desai 2005; Guriev and Rachinsky 2005). The fact is that most of the privatised firms (cement, glass, paper and clay products) were sold to the Ferré Group, a family holding. One of the brothers who ran the group was Luís Ferré, a very important figure in the Statehood Party, and a longstanding opponent of the government's economic policy ${ }^{36}$. At no other time in the history of privatisation has a government sold the bulk of the stateowned manufacturing sector to an opposition political leader. This clearly shows that the sale of the PRIDCO subsidiaries in Puerto Rico was far from being a story of crony capitalism or of transferring government ownership to close political allies in order to foster the government's political interests ${ }^{37}$.

33 When Mussolini was appointed prime minister in October 1922, the Fascist Party had only thirty-five seats in the national parliament out of 535 seats (6.5 per cent). Only three out of thirteen ministers in Mussolini's first cabinet were members of the Fascist Party.

34 The Socialist Party had advocated Puerto Rico's integration in the United States for a long time; this was one of the reasons for the emergence of this apparently paradoxical coalition. Quintero Rivera (1977) and García and Quintero Rivera (1986) contain analyses of the development of working class organisations in Puerto Rico.

${ }^{35}$ Data on the gubernatorial elections were obtained from the Comisión Estatal de Elecciones of Puerto Rico (http://www.ceepur.org/, accessed on June 2, 2009).

${ }^{36}$ In 1968, Luís Ferré became the first non-PPD governor of Puerto Rico, after 20 years of PPD dominance (Muñoz Marín between 1948 and 1964, and Sánchez Vilella between 1964 and 1968).

37 As pointed out by a referee, selling firms to political opponents can be a way of gaining «nonopposition» in Parliament on specific issues and is not per se a signal of government not fostering political interests. In this case, however, it is sensible to believe that the government was not seeking to gain «non-opposition» in Parliament, because Muñoz Marín's PPD had won all the Senatorial and Representative districts in the 1948 election, as stated above. Thus, absolutely all Puerto Rican legislators were members of the ruling party. 


\subsection{Economic Objectives}

Given that ideological biases and partisan political interests did not play a relevant role in privatisation in Puerto Rico, the island's government appears to have privatised in order to advance its economic policy. Even so, it is not as if the Treasury was under great financial pressure (a key factor in most decisions to privatise). The government's public debt had fallen steadily throughout the 1940s, from U.S.\$27.2 million in 1940 to U.S.\$12.8 million in 1949 (this last figure being 47 per cent of the 1940 level) ${ }^{38}$. Interestingly, the lowest level of public debt was reached in 1947 (37 per cent of the 1940 figure), the year in which the first negotiations for privatising PR Shoe and Leather began.

As for industrial policy - the core of Puerto Rican economic policy promoting industrialisation was a primary objective. However, taking into account the large investment in the PRIDCO subsidiaries and the small number of manufacturing jobs created (see Table 2), the amount of capital required to build government factories able to increase production and jobs to the level needed «vastly exceeded the amount available to the government», according to Ross (1957, p. 90). In addition, it should be noted that there were competing demands for public debt, because very large new bond and long-term issues of the public corporations were made in 1949-1950, most of which consisted of obligations of the Water Resources Authority and the Aqueduct and Sewer Authority. Moreover, other government policies that provided subsidies to private firms for establishing industries were much more effective for industrial job creation: «While the government-operated plants employ about 900 persons, they, with the fifty-two privately operated industries started under the Aid Program, are expected to employ a total of around 8,000 persons when their initial development and training programs are completed» (PRIDCO 1949, p. 4).

Another important economic policy objective was to attract foreign capital for the industrialisation process, particularly from the continental United States (Perloff 1950, 1953, p. 51). In this respect, Lewis (1955, p. 625) and Goldsmith et al. (1974, p. 144) stress that an important reason for abandoning nationalisation was to attract investors from the mainland.

Together with the growing impression that the government's main objectives could not be accomplished by means of a full policy of building and operating publicly owned manufacturing firms, the increasing dissatisfaction with the performance of PRIDCO's subsidiaries was probably another key driver of privatisation. Taken as a whole, PRIDCO's subsidiaries were in the black, but only one corporation, PR Cement, was making a profit, and the other four subsidiaries were making heavy losses. Table 4 gathers together information on the profits and losses incurred by each corporation between 1945 and 1950. It is plain to see that only the cement plant recorded

\footnotetext{
${ }^{38}$ Puerto Rico Planning Board, Economic development, p. 81, Table 48.
} 
TABLE 4

NET PROFIT (U.S.\$)/(LOSS) OF PRIDCO CORPORATIONS, 1945-1950

(FISCAL YEAR 1 JULY-30 JUNE)

\begin{tabular}{|l|c|c|c|c|c|}
\hline Corporation & $\mathbf{1 9 4 5 - 4 6}$ & $\mathbf{1 9 4 6 - 4 7}$ & $\mathbf{1 9 4 7 - 4 8}$ & $\mathbf{1 9 4 8 - 4 9}$ & $\mathbf{1 9 4 9 - 5 0}$ \\
\hline PR Cement $^{\mathrm{a}}$ & 457,477 & 499,643 & $1,107,308$ & $1,271,735$ & 758,051 \\
\hline PR Glass & $(138,615)$ & $(138,634)$ & $(518,949)$ & $(316,367)$ & $(174,573)$ \\
\hline PR Pulp and Paper & - & $(41,492)$ & $(271,328)^{\mathrm{b}}$ & $(228,670)^{\mathrm{c}}$ & In liquidation $^{\mathrm{d}}$ \\
\hline PR Shoe and Leather & - & $(47,580)$ & & $(123,596)$ & $(24,505)$ \\
\hline PR Clay Products & - & - & $(155,000)$ & $(112,538)$ & $(114,900)$ \\
\hline
\end{tabular}

Notes: a Until 1944-45, the only subsidiary fully in operation was PR Cement Co. Its profits had been U.S.\$493,865.78 (1942-43), U.S.\$492,674.47 (1943-44), and U.S.\$247,908.78 (1944-45).

${ }^{\mathrm{b}}$ No specific figures for the losses of PR Pulp and Paper Co. and PR Shoe and Leather Co. in 1947-48 were provided. This figure is my own computation for the joint losses based on data in PRIDCO (1948). I found that net loss between July 11947 and April 301948 for each company was: 173,462 — PR Pulp and Paper — and 20,751 — PR Shoe and Leather - (data from Travieso, Information on Subsidiaries' Results). In fact, the loss for the whole fiscal year must have been higher, as the joint computation made for the two subsidiaries shows.

${ }^{\mathrm{c}}$ This figure is my own computation based on information in PRIDCO (1949, pp. 20, 22, 26, 2829 and 36).

${ }^{\mathrm{d}}$ In August 1949, the board of directors of the PR Pulp and Paper Corporation decided to close down the plant and the corporation went into liquidation.

Sources: Author's own data, based on PRIDCO Annual Reports 1947, 1948, 1949, 1950.

profits and that all the other corporations recorded major losses in each of the years studied. Table 5 shows the statement of earned surplus of PRIDCO subsidiaries in 1949 and 1950, the last years of public operation. As can be seen, accumulated deficit in 1950 amounted to U.S.\$1,978,361 (17.3 million in 2010 U.S.\$).

There was also considerable dissatisfaction with the performance of PR Cement. A comparison of its performance with that of Ponce Cement - a private factory owned by the Ferré Group, which had begun production in 1942 - is particularly revealing. In 1943, Ponce Cement's first year of full operation, its production had been 70.4 per cent of that of PR Cement, and Puerto Rico had become a cement exporter in that year. In 1948, the year in which the decision to privatise was firm, Ponce Cement's production figures were 38.1 per cent higher than those of PR Cement (Baralt 1996, p. 127). In addition to the lead Ponce Cement had achieved in production, the differences in price were also an important factor and while Ponce Cement was selling cement at U.S. $\$ 0.75$ per sack PR Cement charged the Puerto Rican government a price of U.S. $\$ 0.95$ (Baralt 1996, p. 177).

The comparison between these two cement factories is important within our context, because the other PRIDCO subsidiaries did not have any competitors on the island (although they faced increasing competition from firms on the 
TABLE 5

EARNED SURPLUS (U.S.\$)/(DEFICIT) OF PRIDCO SUBSIDIARIES, 1949 AND 1950

\begin{tabular}{|l|r|r|r|}
\hline Corporation & \multicolumn{1}{c|}{1949} & \multicolumn{1}{c|}{1950} & \multicolumn{1}{c|}{ Increase } \\
\hline PR Cement $^{\mathrm{a}}$ & $1,527,031$ & $1,472,245$ & 54,786 \\
\hline PR Glass & $(1,221,859)$ & $(1,371,497)$ & $(149,638)$ \\
\hline PR Pulp and Paper $^{\mathrm{b}}$ & $(701,220)$ & $(882,376)$ & $(181,157)$ \\
\hline PR Shoe and Leather & $(211,920)$ & $(497,756)$ & $(285,836)$ \\
\hline PR Clay Products $^{\mathrm{b}}$ & $(435,972)$ & $(780,971)$ & $(344,999)$ \\
\hline Telares PR $^{\text {Other combined surplus, other credits and }}$ & $(78,569)$ & $(79,999)$ & $(1,430)$ \\
\hline other debits $^{\text {Total earned surplus/(deficit) }}$ & $(523,680)$ & $(1,978,361)$ & $(1,454,681)$ \\
\hline
\end{tabular}

PRIDCO: Puerto Rico Industrial Development Company.

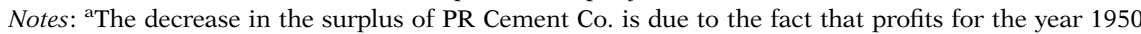
were scarcely above 50 per cent of the previous year. Nevertheless, PR Cement Co. paid the parent company dividends to the tune of U.S. $\$ 800,000$.

${ }^{\mathrm{b}}$ The increase in the deficit of PR Pulp and Paper Co., PR Shoe and Leather Co., and PR Clay Products Co. is partly due to the fact that in those corporations the research and development costs were written off.

Sources: Author's own data, based on PRIDCO Annual Report 1950

U.S. mainland). Puerto Rican policymakers were fully aware of the differences in efficiency and productivity between the cement factories, and of the overall inefficiency of PR Cement, as shown by a confidential report produced by PRIDCO in September 1947 - Report on Puerto Rico Cement performance and productivity - a copy of which was addressed to Muñoz Marín:

1) Whereas the cost of living increased by 53.8 per cent between 1941 and 1947, the average hourly wage at the Puerto Rico Cement Plant increased by 192 per cent in the same period. Whereas the average weekly wage increased by 164 per cent (p. 3), (monetary) labour productivity increased by just 48.5 per cent in the period (p. 4).

2) The annual salary paid at PR Cement was higher than that paid to the island's policemen (first class; by 25.23 per cent), to the island's firefighters (first class; by 87.8 per cent) and to school teachers (by 30.68 per cent) (p. 6).

3) The hourly wage at PR Cement was around 25 per cent higher than in other industrial sectors on the island (p. 9).

4) The hourly wage at PR Cement was around 35.85 per cent higher than at PR Glass, and 87.88 per cent higher than at PR Pulp and Paper (pp. 10-11). 
5) The average weekly wage paid at PR Cement was 20.96 per cent higher than at the Ponce Cement plant. PR Cement employed 24 per cent more workers than Ponce Cement (even though Ponce produced more cement). Efficiency measured as labour productivity at Ponce Cement was 31 per cent higher (p. 12).

The points stressed in this report provide a depressing image of PR Cement's efficiency and productivity and must have made a lasting impression on Puerto Rican policymakers ${ }^{39}$. The situation raised two particular concerns. First, the wage policy in PRIDCO's subsidiaries needed reforms in order to make them profitable, but PRIDCO's managers could never deal satisfactorily with this issue because of its political repercussions (Moscoso 1953 , p. 61 $)^{40}$. Second, wages paid to PRIDCO's manufacturing workers, especially those in PR Cement, were pushing industrial salaries in Puerto Rico upwards, with negative effects on the island's competitiveness and its ability to attract foreign investment (Lewis 1955, p. 627) ${ }^{41}$.

In stark contrast to the government's plants, the Ferré Group's companies had a fine record of productive efficiency (Muñoz Marín 1992, p. 253). Furthermore, Muñoz Marín saw José Ferré, the head of the family business, as an exemplary Puerto Rico entrepreneur, the very opposite of the widespread model of absentee owner that - to his mind - had been one of the main obstacles to the success of local industrialisation ${ }^{42}$. These factors,

39 As mentioned above, the absence of private competitors for the manufacturing subsidiaries other than cement makes it impossible to compare public vs. private efficiency before privatisation any further. In the same way, the lack of data for the post-privatisation period makes it impossible to compare the pre- and post-privatisation performance of the subsidiaries sold to the Ferré Group. Nevertheless, some comparison on productivity can be made for the case of PR Shoe and Leather, which was sold to Joyce of Puerto Rico in 1949. The productivity per worker at the end of fiscal year 1947-1948 (June 1948) was 2.8 pairs of shoes per day (computation based on production data from PRIDCO (1949, p. 26); data on the workforce in Table 2). In the last month of fiscal year 1950 (June 1950), already under private management, production was 3.5 pairs of shoes per worker per day (computation based on data in PRIDCO 1950, p. 20). In any case, it is worth noting that this information was not available at the time privatisation was decided.

${ }^{40} \mathrm{He}$ also stressed the fact that, even though the government factories were organised as corporations, PRIDCO had many responsibilities to different government agencies. Because of the lack of coordination between the departments of the government, the burden of compliance was excessive (p. 68).

${ }^{41}$ The effect of wages on industrial competitiveness was an important concern for PRIDCO's top management. Following the Democratic victory in the 1948 U.S. presidential and legislative election (supported by the PPD), Moscoso sent a memorandum to Piñero, Múñoz Marín, and Fernós Isern (Resident Commissioner of Puerto Rico) stating that «the industrialization program may be absolutely destroyed if Puerto Rico is not allowed to maintain the privilege held until now of establishing minimum wages through industrial committees». Taking for granted that the Democratic victory would result in an increase of the minimum wage in the United States, Moscoso added «there will be pressure to fully include Puerto Rico in the federal law. Should this happen, the industrialization program would be immediately terminated.» (Moscoso. Memorandum to Jesús T. Piñero, Luis Múñoz Marín, and A. Fernós Isern; author's translation).

${ }^{42}$ This can be seen in Muñoz Marín, Memorias. I owe this insight to Silvia Álvarez Curbielo. 
together with the fact that the bid submitted by the Ferre Group was the best received for the PRIDCO subsidiaries, explains how and why the sale of the four remaining factories was decided in October 1950.

In 1950, the industrial development programme was reorganised. The Economic Development Administration (EDA) was created as a regular department of the Puerto Rican government, operating with funds assigned annually by the Legislature. The proceeds obtained from the sale of PRIDCO's subsidiaries were used to promote EDA's activities, and a new phase of industrial policy in Puerto Rico - the analysis of which is beyond the scope of this paper - became consolidated ${ }^{43}$.

\section{CONCLUSION}

A large SOE sector was created in Puerto Rico in the 1940s, a period in which the island's governor was still appointed by the U.S. President. Several public services were nationalised and manufacturing SOEs were created to produce cement, glass, shoes, paper and clay products. Between 1948 and 1950, the first elected government in Puerto Rico privatised the manufacturing SOEs, thus implementing the first large-scale privatisation policy in a democracy.

This study contributes to the literature by documenting the privatisation process in Puerto Rico, and by analysing the roles played by ideology, political interests and economic objectives in the decision to privatise. Ideological bias and partisan political objectives do not appear to have driven privatisation in Puerto Rico. Unfortunately, the economic and financial information for the manufacturing SOEs is limited. However, the available data suggest that pragmatic economic concerns, related to the performance of the government's manufacturing firms, together with the need to attract private investment to foster industrialisation in the island, seem to have been the main forces behind it.

At the end of the 1940s, Puerto Rico's policymakers applied a highly practical approach to their policies for promoting industrialisation. Increasing dissatisfaction with the performance of the manufacturing SOEs, together with

${ }^{43}$ Most of the papers published in the monograph «Puerto Rico. A study in Democratic Development» (Annals of the American Academy of Political and Social Science; vol. 285, January 1953) emphasized the highly successful results of this strategy in the short run. These results probably contributed to Muñoz Marín's performance in the 1952 gubernatorial election, when he polled 64.9 per cent of the votes, an all-time high. The Independent Party came second, with 19 per cent. The two parties that had come second in 1948 running as a coalition fared very badly in 1952: the Statehood Party obtained only 12.9 per cent, and the Socialist Party 3.3 per cent. Muñoz Marín retained strong electoral support through his entire career as governor: in the 1960 election, the last time he ran, he obtained 58.2 per cent of votes. In 1964, his successor as PPD candidate, Sánchez Vilella, obtained 59.2 per cent. This said, it is worth noting that other analyses of the bootstrap strategy are more critical. For instance, Weisskoff (1985) points out that with that strategy the field was left to whoever wanted to use relatively cheap labor and take advantage of the tax evasion and transfer pricing schemes, eventually creating problems of high unemployment and little net labor opportunity. 
improved opportunities for stimulating privately induced industrialisation, suggested that the experiment of government-owned manufacturing firms should be terminated. A strong political leadership was able to deliver this policy reform.

To conclude, it is worth stressing that privatisation in Puerto Rico was far from being a story of crony capitalism or of coalition building to foster the government's political interests. It diverged radically from the previous instances of a policy of privatisation implemented between 1922 and 1925 by the Fascist government in Italy, and between 1934 and 1937 by the Nazi government in Germany. Democracy, which implies checks and balances, transparency, and public scrutiny, may well provide an environment that is less prone to corruption and less politically tainted privatisation than a dictatorship. Future research should undertake a more thorough study of the differences between privatisation under democracy and under a dictatorship.

\section{SOURCES}

Government internal memorandums and personal correspondence (Fundación Luís Muñoz Marín)

BAIRD, D. G. Letter from David G. Baird (Vice-President of Marsh \& McLennan Inc.) to Puerto Rican Industrial Development Company (Att: Mr. Teodoro Moscoso), February 1, 1949.

Moscoso, T. Letter from Teodoro Moscoso to Rexford Tugwell, June 30, 1945.

Moscoso, T. Letter from Teodoro Moscoso to Luis Muñoz Marín, June 24, 1948 (original in Spanish).

Moscoso, T. Memorandum from Teodoro Moscoso to Jesús T. Piñero, Luis Múñoz Marín, and A. Fernós Isern, November 9, 1948 (original in Spanish).

PRIDCO. Minutes of the Meeting of the Planning and Executive Committees of the Puerto Rico Industrial Development Company held on Friday, May 30, 1947, at 9:00 am.

PRIDCO. Report on Puerto Rico Cement Performance and Productivity. Elaborated by PRIDCO on September 1947, and addressed to Luis Muñoz Marín (original in Spanish).

PRIDCO. Proposal for the Sale of Subsidiaries of the Development Company. Internal Memorandum, May 11, 1948.

PRIDCO. Memorandum from Teodoro Moscoso to Board of Directors. February 7, 1949 (original in Spanish).

Travieso, L. F. Information on Subsidiaries' Results of Operation. Memorandum sent to Teodoro Moscoso on June 1, 1948 (original in Spanish).

\section{OFFICIAL PUBLICATIONS}

PR Government (1943, 1944, 1945, 1946, 1947, 1948, 1949, 1950): Annual Report of the Governor of Puerto Rico (Forty-Third, Forty-Fourth, Forty-Fifth, 
Forty-Sixth, Forty-Seventh, Forty-Eighth, Forty-Ninth, Fiftieth). San Juan: Puerto Rico Government.

PRDC (1944): Annual Report 1944. San Juan: Puerto Rico Development Company.

PRIDCO (1947, 1948, 1949, 1950, 1951): Annual Report. San Juan: Puerto Rico Industrial Development Company.

Puerto Rico Planning Board (1951): Economic Development of Puerto Rico, 1940-1950 and 1951-1960. San Juan: Puerto Rico Planning Board.

Puerto Rico Planning Board (1952): Informe económico al Gobernador 19501951. San Juan: Junta de Planificación de Puerto Rico (original in Spanish).

Tugwell, R. G. (1942): Message of the Governor of Puerto Rico to the Fifteenth Legislature at its Second Regular Session, 10 February. San Juan: Puerto Rico Government.

Tugwell, R. G. (1946): Message of the Governor of Puerto Rico to the Sixteenth Legislature at its Second Regular Session, 12 February. San Juan: Puerto Rico Government.

\section{REFERENCES}

BAER, W. (1959): «Puerto Rico: An Evaluation of a Successful Development Program». Quarterly Journal of Economics 73 (4), pp. 645-671.

Baralt, G. (1996): La vida de Luis A. Ferré. Volumen I: 1904-1968. San Juan: Fundación El Nuevo Día.

BeL, G. (2006): «The Coining of 'Privatization' and Germany's National Socialist Party». Journal of Economic Perspectives 20 (3), pp. 187-194.

BeL, G. (2010): "Against the Mainstream: Nazi Privatization in 1930s Germany». Economic History Review 63 (1), pp. 34-55.

Bel, G. (forthcoming): «The First Privatization: Selling SOEs and Privatizing Public Monopolies in Fascist Italy (1922-1925)». Cambridge Journal of Economics.

Bel, G., and Calzada, J. (2009): "Privatization and Universal Services Obligations». Journal of Institutional and Theoretical Economics 165 (4), pp. 650-669.

BeL, G., and Fageda, X. (2009): «Factors Explaining Local Privatization: A MetaRegression Analysis». Public Choice 139 (1/2), pp. 105-119.

Biais, B., and Perotti, E. (2002): «Machiavellian Privatization». American Economic Review 92 (1), pp. 240-258.

Bortolotti, B.; Fantini, M., and Siniscalco, D. (2003): «Privatisation Around the World: Evidence from Panel Data». Journal of Public Economics 88 (1/2), pp. 335-366.

Bortolotti, B., and Milella, V. (2008): «Privatization in Western Europe. Stylized Facts, Outcomes, and Open Issues», in G. Roland (ed.), Privatization: Successes and Failures. New York: Columbia University Press, pp. 32-75.

Boycko, M.; Shleifer, A., and Vishny, R. W. (1996): «A Theory of Privatization». Economic Journal 106 (435), pp. 309-319.

BuRk, K. (1988): The First Privatization: The Politicians, the City, and the Denationalisation of Steel. London: Historians' Press.

CARR, R. (1984): Puerto Rico: A Colonial Experiment. New York: New York University Press. 
Chase, S. (1951): «Operation Bootstrap» in Puerto Rico. Report of Progress 1951. National Planning Association, Planning Pamphlets, n. 75, September 1951.

Clifton, J.; Comín, F., and Díaz Fuentes, D. (2003): Privatisation in the European Union. Dordrecht: Kluwer Academic Publishers.

Desai, P. (2005): «Russian Retrospectives on Reforms from Yeltsin to Putin». Journal of Economic Perspectives 19 (1), pp. 87-106.

Descartes, S. L. (1950): Financing Economic Development in Puerto Rico 1941-1949. San Juan: Government of Puerto Rico Department of Finance.

Dietz, J. L. (1986): The Economic History of Puerto Rico. Institutional Change and Capitalist Development. Princeton, NJ: Princeton University Press.

García, G., and Quintero Rivera, Á. (1986): Desafío y solidaridad: Breve historia del movimiento obrero puertorriqueño. Ríos Piedras: Ediciones Huracán.

Goldsmith, W. W.; Clavel, P., and Roth, D. (1974): «A Bibliography of Public Planning in Puerto Rico». Latin American Research Review 9 (2), pp. 143-169.

Gómez-Iвáñez, J. A. (2003): Regulating Infrastructure. Monopoly, Contracts, and Discretion. Cambridge, Mass.: Harvard University Press.

Goodsell, C. T. (1965): Administration of a Revolution. Executive Reform in Puerto Rico Under Governor Tugwell, 1941-1946. Cambridge, Mass.: Harvard University Press.

GuRIEv, S., and RachinSKY, A. (2005): "The Role of Oligarchs in Russian Capitalism». Journal of Economic Perspectives 19 (1), pp. 131-150.

Lewis, G. K. (1955): «Puerto Rico: A Case-Study of Change in an Underdeveloped Area». Journal of Politics 17 (4), pp. 614-650.

Maldonado, A. W. (1965): "Tugwell: The Forgotten Man». Sunday San Juan Star Magazine, 26 September 1965, p. 3.

Maldonado, A. W. (1997): Teodoro Moscoso and Puerto Rico's Operation Bootstrap. Gainesville, FL: University Press of Florida.

Megginson, W. L. (2005): The Financial Economics of Privatization. New York: Oxford University Press.

MerLin, S. (1943): «Trends in German Economic Control since 1933». Quarterly Journal of Economics 57 (2), pp. 169-207.

Moscoso, T. (1953): "Industrial Development in Puerto Rico». Annals of the American Academy of Political and Social Sciences 285, pp. 60-69.

Muñoz Marín, L. (1992): Luis Muñoz Marín, Memorias, Autobiografía pública, 1940-1952. San Germán: Centro de Publicaciones de la Universidad Interamericana de Puerto Rico (San Juan: Fundación Luis Muñoz Marín, 2003).

Muñoz Marín, L. (2005): Palabras: Luis Muñoz Marín, 1945-1948. San Juan: Fundación Luis Muñoz Marín.

Neville, G. W. (1950): Denationalisation in Practice. London: The Individualist Bookshop Limited.

OsudA, K. (1954): The Industrial Development Program in Puerto Rico, 1942-1953. Cambridge, Mass.: Unpublished PhD thesis, Harvard University.

Organization for Economic Cooperation and Development (2005): National Accounts for OECD Countries Vol. IIIa: Financial Accounts-Flows and Vol. IIIb: Financial Balance Sheets-Stocks, 1993-2004. Paris: OECD.

Perloff, H. S. (1950): Puerto Rico's Economic Future. Chicago, IL: The University of Chicago Press.

Perloff, H. S. (1953): «Transforming the Economy». Annals of the American Academy of Political and Social Sciences 285, pp. 48-54.

Perotti, E. C. (1995): «Credible Privatization». American Economic Review 85 (4), pp. 847-859. 
Quintero Rivera, Á. (1977): Conflicto de clase y politica en Puerto Rico. San Juan: Centro para el Estudio de la Realidad Puertorriqueña.

Richardson, L. C. (1947): Puerto Rico Caribbean Crossroads. New York: Camera Publishing Corp.

Ross, D. F. (1957): «Gordon Lewis on Puerto Rico’s Development Program». Journal of Politics 19 (1), pp. 86-100.

Ross, D. F. (1966): The Long Uphill Path. A Historical Study of Puerto Rico's Program of Economic Development. San Juan: Talleres Gráficos Interamericanos [San Juan (PR): Editorial Edil, 1969].

Schipke, A. (2001): Why Do Governments Divest? The Macroeconomics of Privatization. Berlin: Springer-Verlag.

Shleifer, A., and VishnY, R. W. (1994): «Politicians and Firms». Quarterly Journal of Economics 109 (4), pp. 995-1025.

SweEzy, M. Y. (1941): The Structure of the Nazi Economy. Cambridge, Mass.: Harvard University Press.

Tugwell, R. G. (1947): The Stricken Land. Garden City, NY: Doubleday \& Company Inc.

Tugwell, R. G. (1953): «What Next for Puerto Rico?». Annals of the American Academy of Political and Social Sciences 285, pp. 145-152.

Vickers, J., and Yarrow, G. (1988): Privatization: An Economic Analysis. London: MIT Press.

Vickers, J., and Yarrow, G. (1991): «Economic Perspectives on Privatization». Journal of Economic Perspectives 5 (2), pp. 111-132.

Weisskoff, R. (1985): Factories and Food Stamps: The Puerto Rico Model of Development. Baltimore, MD: Johns Hopkins University Press.

Yarrow, G. (1999): "A Theory of Privatization, or Why Bureaucrats Are Still in Business». World Development 27 (1), pp. 157-168.

Yergin, D., and Stanislaw, J. (1998): The Commanding Heights. The Battle between Government and the Marketplace that is Remaking the Modern World. New York: Simon \& Schuster. 